\title{
AN INTEGRATED FUZZY ANALYTIC HIERARCHY PROCESS-FUZZY DATA ENVELOPMENT ANALYSIS (FAHP-FDEA) METHOD FOR INTELLIGENT BUILDING ASSESSMENT
}

\author{
Afshar Sahraei Loron, Mehrdad Sahraei Loron, Ghazal Peyvandi
}

Original scientific paper

In the recent years, organizations and researchers have been focused on the intelligent building assessment in building design and construction. The performance of intelligent buildings (IBs) is measured based on the IB related characteristics and actual circumstances. This paper utilizes the fuzzy set theory, analytic hierarchy process (AHP), and data envelopment analysis (DEA), and offers an integrated fuzzy AHP-fuzzy DEA (FAHP-FDEA) method for intelligent building assessment. The fuzzy set theory is used to model the imprecise and vague data of the evaluation criteria. Since, the evaluation criteria have different importance in the evaluation process; FAHP is employed to determine the weight of criteria. Then, the weight of criteria is incorporated to a FDEA model to measure the intelligent buildings' performance. The pure fuzzy AHP method can only compare a very limited number of decision alternatives, while the proposed FAHP-FDEA can rank a huge number of alternatives. A case study taken from the literature is considered to show applicability and effectiveness of the proposed FAHP-FDEA model. The results affirmed that the proposed method provides the consistent results with the existing methods in the literature. In addition, the proposed method enables decision makers to determine the results under different aspiration levels.

Keywords: decision making; FAHP, FDEA; fuzzy set theory; intelligent building assessment

\author{
Integrirana metoda fuzzy analitičkog hijerarhijskog postupka i fuzzy analize podataka grupe (FAHP-FDEA) u ocjenjivanju \\ inteligentne zgrade
}

Izvorni znanstveni članak Zadnjih su godina u projektiranju i izgradnji građevina organizacije i istraživači usredotočeni na ocjenu inteligentne zgrade. Performanse inteligentnih zgrada (IB) mjere se na temelju karakteristika koje se odnose na IB i stvarnih okolnosti. U ovom se radu koristi teorija fuzzy niza, analitički hijerarhijski postupak (AHP) i analiza podataka grupe (data envelopment analysis - DEA), i nudi integrirana fuzzy AHP-fuzzy DEA (FAHP-FDEA) metoda za ocjenu inteligentne zgrade. Primjenjuje se teorija fuzzy niza za modeliranje nepreciznih i neodređenih podataka ocjenjivačkih kriterija. Budući da su oni od različite važnosti u postupku ocjenjivanja, za određivanje težine kriterija primjenjuje se FAHP. Tada se težina kriterija uključuje u FDEA model kako bi se dobila ocjena performanse inteligentne zgrade. Čistom fuzzy AHP metodom moguće je usporediti samo vrlo ograničen broj alternativa za donošenje odluke dok se predloženom FAHP-FDEA metodom može rangirati ogroman broj alternativa. Razmotrena je analiza slučaja uzetog iz literature da bi se pokazala primjenjivost i učinkovitost predloženog modela FAHP-FDEA. Rezultati su potvrdili da se predloženom metodom dobivaju rezultati u skladu s postojećim metodama u literaturi. Uz to, predloženom se metodom omogućuje da donosioci odluke rezultate donesu u skladu s težnjama.

Ključne riječi: donošenje odluke; FAHP; FDEA; ocjena inteligentne zgrade; teorija fuzzy niza

\section{Introduction}

Intelligent building is a new concept in building design and construction. It focused on the major technological systems and addressed building automation, communications and office automation. In addition, it aims to improve the building performance to satisfy a variety of human needs and environmental sustainability $[1,2] . T h e r e$ are different definitions of intelligent building in the literature survey. For instance, European Intelligent Building Group (EIBG) expressed IB in the following way: "Intelligent building is one that incorporates the best available concepts, materials, systems and technologies, integrating these to achieve a building which meets or exceeds the performance requirements of the building stakeholders, which include the owners, managers and users, as well as the local and global community". As highlighted in [3], the definition of Intelligent Building Institution in Washington is 'one which integrates various systems to effectively manage resources in a coordinated mode to maximize technical performance, investment and operating cost savings, and flexibility'.

Implementation of intelligent building technologies has several advantages. For example, it enhances operational and energy efficiency, improves cost effectiveness, increases system robustness and reliability, and improves the user comfort and productivity [4].
Therefore, the building intelligence performance measurement is highly recommended in the literature [5]. Wong et al. [6] discuss that researchers were focused on the performance measurement of intelligent building alternatives based on financial criteria and ignored nonfinancial criteria. However, non-financial evaluation criteria are also important in the evaluation process [7].

The recent studies have tried to develop performance evaluation frameworks and models due to the growing demands being placed on the industry by its clients. Most of these frameworks and models are inspired by multicriteria decision making (MCDM) models such as analytic hierarchy process (AHP), analytic network process (ANP), and TOPSIS. Chen et al. [8] proposed an ANP method to measure the lifespan energy efficiency of IBs. Kolokotsa et al. [9] proposed a methodology for evaluating the buildings' intelligence by developing a matrix tool. Wong and Li [10] developed a MCDM model inspired by the AHP approach to measure the performance of IB systems. To determine the key issues related to sustainable intelligent buildings, ALwaer and Clements-Croome [11] developed conceptual model based on the AHP method for the selection of the appropriate key performance indicators (KPIs).

A Knowledge-oriented Information Visualization (KIV) approach is developed by Hong et al. [12]. They developed approach facilitates implementing the building rating systems for the post assessment of IBs. Asian 
Institute of Intelligent Buildings introduced the intelligent building index (IBI) for quantitative assessment of IBs. The index is inspired from the nine quality environment modules, and can give a score from 1 to 100 . A building can be ranked from $\mathrm{A}$ to $\mathrm{E}$ to indicate the overall intelligent performance [13]. Preiser and Schramm [14] developed three stages procedure for the post-occupancy evaluation process. The proposed procedure identifies the intelligence level of intelligent buildings. Arkin and Paciuk [15] developed a measure called the "Magnitude of Systems' Integration" Index (MSIR) to determine the level of systems' integration of intelligent buildings. Yang and Peng [16] employed the MSIR model for IB alternative assessment.

Fuzzy set theory is a flexible tool for handling various types of uncertainty. It can handle the epistemic uncertainty that comes from the lack of information about the actual value of evaluation criteria. Some researchers employed the fuzzy set theory and MCDM models to assess the intelligent building alternatives. For instance, Kahraman and Kaya [17] proposed a fuzzy multiple attribute utility (MAUT) model for an intelligent building evaluation. Furthermore, Kaya and Kahraman [18] proposed fuzzy TOPSIS and fuzzy AHP for intelligent building assessment. This paper develops an integrated fuzzy AHP-fuzzy DEA (FAHP-ADEA) method for intelligent building assessment under fuzzy environment. FAHP method is applied to identify the weight of criteria. Then, the weight of criteria is incorporated to a FDEA model to measure the intelligent buildings' performance. A case study taken from the literature is also considered to show applicability and effectiveness of the proposed FAHP-FDEA model. The fuzzy AHP method is particularly suitable for modelling qualitative criteria and has found extensive applications in a wide variety of areas such as selection, evaluation, planning and development, decision making forecasting, and so on. However, when there are many decision alternatives to be evaluated and prioritized, the pair-wise comparison matrix is obviously infeasible in this situation and consequently, the AHP method fails. Therefore, it can only compare a very limited number of decision alternatives. To overcome this difficulty, we combine the fuzzy AHP with the fuzzy DEA method. Five important criteria, namely, engineering, environmental, economical, socio-cultural, and technological criteria, are used in most of the researches for intelligent building assessment $[5,8,10$, $11,18]$. Therefore, we use these criteria for measuring the three intelligent building alternatives.

The rest of this paper is organized as follows: fuzzy DEA model is introduced in Section 2. The proposed FAHP-FDEA method is explained step by step in Section 3. Application of the proposed model is illustrated through a case study taken from the literature in Section 4. Concluding remarks are discussed in Section 5.

\section{Fuzzy DEA method}

Data Envelopment Analysis (DEA), which was introduced by Charns et al. [19], is a useful tool for performance measurement and management. It consists of a set of linear programming technique that constructs empirical production frontiers and evaluates the relative efficiency of Decision Making Units (DMUs) by considering multiple inputs and multiple outputs. In the conventional DEA models, it is assumed that all inputoutput data are exact. However, in some real world applications, the data may be imprecise. In this manner, fuzzy set theory is a well-known approach to handle the imprecise and inexact data. In this section, we briefly introduce the Fuzzy DEA (FDEA) model developed by Saaty et al. [20] in this paper. To do this, suppose there are $n$ decision making units (DMUs) that use $m$ inputs $\left(\tilde{x}_{i j}=\left(x_{i j}^{m}, x_{i j}^{l}, x_{i j}^{u}\right), i=1,2, \ldots, m\right)$ to produce $s$ outputs $\left(\tilde{y}_{r j}=\left(y_{r j}^{m}, y_{r j}^{m}, y_{r j}^{m}\right), r=1,2, \ldots, s\right)$. The fuzzy DEA model proposed by Saaty et al. [20] is $\alpha$-parametric linear programming model, which helps decision makers to provide the efficiency of each DMU with different $\alpha$ in $(0$, 1]. The initial proposed fuzzy DEA model could not provide full ranking for all DMUs in the case where there are several efficient units with efficiency of 1 . Therefore, the authors developed other fuzzy DEA model for ranking all DMUs, especially efficient DMUs. To obtain the efficiency score and the rank of $p^{\text {th }}$ DMU, the following fuzzy DEA model should be solved [20]:

$$
\begin{aligned}
& \min Z=\theta \\
& \text { s.t. } \theta\left(\alpha x_{i p}^{m}+(1-\alpha) x_{i p}^{l}\right) \geq \sum_{j=1}^{n} \lambda_{j}\left(\alpha x_{i j}^{m}+(1-\alpha) x_{i j}^{u}\right) \quad \forall i \\
& \alpha y_{r p}^{m}+(1-\alpha) y_{r p}^{u} \leq \sum_{j=1}^{n} \lambda_{j}\left(\alpha y_{r j}^{m}+(1-\alpha) y_{r j}^{l}\right) \quad \forall r \\
& \lambda_{j} \geq 0 \quad \forall r
\end{aligned}
$$

where $\alpha$ denotes a parameter in $(0,1]$. The above model compared the best part of DMU (i.e., the lower level of inputs and upper level of outputs) with the inner part of efficiency frontier to rank DMUs. If in this case the best part of DMU may go out of this part of frontier, then an efficiency score more than one will be assigned to it. So, by this idea, all DMUs will be ranked.

\section{Integrated FAHP-FDEA method}

In this section, we propose a FAHP-FDEA method for intelligent building assessment. The proposed model utilizes the fuzzy AHP to calculate the weight of criteria. Then, the obtained criteria are incorporated in the fuzzy DEA to assess alternatives. The main steps of the integrated FAHP-FDEA are as follows:

Step 1: In this step, the pairwise comparison matrices are obtained. Suppose $\tilde{c}_{i j}$ denotes the element of the $i^{\text {th }}$ row with respect to the $j^{\text {th }}$ column of pairwise comparison matrix (C). Each $\tilde{c}_{i j}$ element is defined as a linguistic term, which shows the importance of one criterion over the other. The pairwise comparison matrix can be written as follows:

$$
\widetilde{C}_{k}=\left|\begin{array}{cccc}
1 & \widetilde{c}_{12} & \cdots & \widetilde{c}_{1 n} \\
\widetilde{c}_{21} & 1 & \cdots & \widetilde{c}_{2 n} \\
\vdots & \vdots & \ddots & \vdots \\
\widetilde{c}_{n 1} & \widetilde{c}_{n 2} & \cdots & 1
\end{array}\right|, k=1,2, \ldots, K,
$$


where $\tilde{C}_{k}$ denotes the pairwise comparison matrix, which is obtained from the kth expert' opinions. According to Hsieh et al. [21], the scales represented in Tab. 1, can be used for evaluation procedure. To aggregate the expert opinions, the geometric mean is applied.

Table 1 Linguistic scale for weight matrix

\begin{tabular}{|c|l|c|}
\hline Linguistic scales & Scale of fuzzy number & \\
\hline$(1,1,3)$ & Equally important & $(\mathrm{Eq})$ \\
\hline$(1,3,5)$ & Weakly important & $(\mathrm{Wk})$ \\
\hline$(3,5,7)$ & Essentially important & $(\mathrm{Es})$ \\
\hline$(5,7,9)$ & Very strongly important & $(\mathrm{Vs})$ \\
\hline$(7,9,9)$ & Absolutely important & $(\mathrm{Ab})$ \\
\hline
\end{tabular}

Step 2: Local fuzzy weights are obtained for each pairwise comparison matrix. To do this end, the following mathematical relations are applied:

$$
\begin{aligned}
& \tilde{r}_{i}=\left(\widetilde{c}_{i 1} \otimes \widetilde{c}_{i 2} \otimes \ldots \otimes \widetilde{c}_{i n}\right)^{\frac{1}{n}}, \\
& \widetilde{w}_{i}=\widetilde{r}_{i} \otimes\left(\widetilde{r}_{1} \otimes \widetilde{r}_{2} \otimes \ldots \otimes \widetilde{r}_{n}\right)^{-1},
\end{aligned}
$$

where $\tilde{r}_{i}$ denotes the geometric mean of fuzzy comparison value and $\tilde{w}_{i}$ shows the fuzzy local weight of the $i^{\text {th }}$ criterion, which is in the form of triangular fuzzy number $\tilde{w}_{i}=\left(L_{i}, M_{i}, U_{i}\right)$.

Step 3: In this step, the global weights of criteria $\left(\tilde{w}_{j}^{G}\right)$ are calculated by multiplying the local weight of each criteria to the weight of its sub-criteria according to the AHP procedure.

Step 4: choose the linguistic rating for alternatives with respect to criteria. For doing so, Tabs. 2 and 3 can be used. Suppose, there are $\mathrm{K}$ experts and $\tilde{x}_{i j}^{k}$ indicates the fuzzy rating for alternative $\mathrm{j}$ with respect to the $i^{\text {th }}$ criterion that belongs to the kth expert. Then, the aggregated fuzzy rating $\tilde{x}_{i j}$ can be calculated as:

$\tilde{x}_{i j}=\frac{1}{K} \sum_{k=1}^{K} \widetilde{x}_{i j}^{k}$.

Table 2 Linguistic variables for the importance weight of each criterion

\begin{tabular}{|l|l|}
\hline Very low (VL) & $\left(\begin{array}{lll}0 & 00,1\end{array}\right)$ \\
\hline Low (L) & $\left(\begin{array}{lll}0 & 0,1 & 0,3\end{array}\right)$ \\
\hline Medium low (ML) & $\left(\begin{array}{lll}0,1 & 0,3 & 0,5\end{array}\right)$ \\
\hline Medium (M) & $\left(\begin{array}{lll}0,3 & 0,5 & 0,7\end{array}\right)$ \\
\hline Medium high (MH) & $\left(\begin{array}{lll}0,5 & 0,7 & 0,9\end{array}\right)$ \\
\hline High (H) & $\left(\begin{array}{lll}0,7 & 0,9 & 1\end{array}\right)$ \\
\hline Very high (VH) & $\left(\begin{array}{lll}0,9 & 1 & 1\end{array}\right)$ \\
\hline
\end{tabular}

\begin{tabular}{|c|c|}
\hline Very poor (VP) & $\left(\begin{array}{lll}0 & 0 & 1\end{array}\right)$ \\
\hline Poor $(\mathrm{P})$ & $\left(\begin{array}{llll}0 & 1 & 3\end{array}\right)$ \\
\hline Medium poor (MP) & $(135)$ \\
\hline Fair $(\mathrm{F})$ & $(357)$ \\
\hline Medium good (MG) & $(579)$ \\
\hline Good $(\mathrm{G})$ & $(7910)$ \\
\hline Very good (VG) & 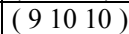 \\
\hline
\end{tabular}

Table 3 Linguistic variables for the ratings

Step 5: In this step, the normalized fuzzy decision matrix is constructed based on the aggregated fuzzy ratings. The normalized fuzzy decision matrix $\widetilde{\boldsymbol{R}}=\left[\widetilde{r}_{i j}\right]_{m \times n}$ can be calculated as follows:

$\tilde{r}_{i j}=\left(\frac{a_{i j}}{c_{j}^{\max }}, \frac{b_{i j}}{c_{j}^{\max }}, \frac{c_{i j}}{c_{j}^{\max }}\right), j \in B$,

$\widetilde{r}_{i j}=\left(\frac{a_{j}^{\min }}{c_{i j}}, \frac{a_{j}^{\min }}{b_{i j}}, \frac{a_{j}^{\min }}{a_{i j}}\right), j \in C$,

$c_{j}^{\max }=\max _{i} c_{i j}$ if $j \in B$,

$a_{j}^{\min }=\min _{i} a_{i j}$ if $j \in C$,

where $B$ and $C$ denote the set of benefit and cost type criteria, respectively.

Step 6: Obtain the weighted normalized fuzzy decision matrix $\tilde{\boldsymbol{V}}=\left[\widetilde{v}_{i j}\right]_{m \times n}$ based on the following formulations.

$\widetilde{\boldsymbol{V}}=\boldsymbol{R} \otimes \widetilde{W}^{G}$,

$\widetilde{v}_{i j}=\widetilde{r}_{i j} \otimes \widetilde{w}_{j}^{G}$,

where $\tilde{W}^{G}$ and $\tilde{w}_{j}^{G}$ are the global vector weight and global weight of the $j^{\text {th }}$ criterion, respectively.

Step 7: Apply the FDEA model on the weighted normalized fuzzy decision matrix and obtain the rank of alternatives. It is worth mentioning that all columns of the weighted normalized fuzzy decision matrix are benefittype sub-criteria. Therefore, they are considered as outputs of the FDEA model. In this manner, according to Liu et al. [21], we consider one dummy input of $\tilde{1}=(1,1,1)$ for all DMUs.

\section{Application}

To illustrate the application and effectiveness of the integrated FAHP-DEA model for intelligent building assessment, a case study is considered which is previously introduced in [17]. The rapid development of the service sector, demand for high-rise office buildings in Istanbul, has led to the completion of many high rises in the recent years. This case study is addressed to assessing three intelligent building alternatives, namely, IB-A, IB-B, and IB-C, based on several criteria. The criteria and their subcriteria are obtained from the concerned literature $[5,8$, 10, 11, 18], and presented in Tab. 4. Furthermore, the hierarchical structure of the problem is shown in Figure 1.

According to Kahraman and Kaya [17], the linguistic scales introduced in Section 3 are used to evaluate all criteria. Furthermore, alternatives for intelligent building assessment are evaluated by using four experts' opinions in this real case application. The first three experts are professors in Civil Engineering, Mechatronics Engineering, and Computer Engineering, respectively. The fourth expert is a top manager in the construction sector.

To obtain the weight of the criteria and their subcriteria, the linguistic evaluations are first collected by 
using the experts' opinions. Then, they are converted to fuzzy numbers according to Tab. 1. After that, the geometric mean is used to aggregate expert opinions and calculate the fuzzy pairwise comparison matrix. For instance, the fuzzy pairwise comparison matrix for the main criteria is presented in Tab. 5. The fuzzy local weights are calculated for each pairwise comparison matrix according to Eq. (2). Finally the fuzzy global weights are obtained. The fuzzy weights of the criteria and their sub-criteria, and the fuzzy global weights are reported in Tab. 6.

The rating of alternatives with respect to criteria is obtained by collecting the experts' opinions. The linguistic variables are utilized to evaluate the ratings of alternatives. Then the normalized fuzzy decision matrix is calculated by aggregating the experts' opinions for the rating of alternatives and using Eq. (4). The weighted normalized fuzzy decision matrix is also calculated according to step 6 . The respected results are reported in Tab. 7.
Finally, we applied the fuzzy DEA model presented in Section 2 on the weighted normalized fuzzy decision matrix. To this end, the intelligent building alternatives, i.e., IB-A, IB-B, and IB-C, are considered as DMUs in the FDEA model. Furthermore, all sub-criteria are considered as the output variables and a fuzzy number $\left(\begin{array}{lll}1 & 1 & 1\end{array}\right)$ is considered as a dummy input for each DMU. Then, the FDEA model is solved for each DMU to determine its rank. The score and ranking results for each DMU are reported in Tab. 8. The FDEA model determines the score of 1 for all alternatives at $\alpha=1$, and hence cannot discriminate alternatives at this $\alpha$-level. However, according to these results, it can be affirmed that at each $\alpha$-level except $\alpha=1$, the best alternative is alternative IB-B for an intelligent building. Furthermore, IB-C is the worst alternative. Therefore, at each $\alpha$-level, the ranking of alternatives is determined as IB-B $>$ IB-A $>$ IB-C. This ranking result is also consistent with that obtained by fuzzy MAUT introduced by Kahraman and Kaya [17], and fuzzy TOPSIS and fuzzy AHP developed in [18].

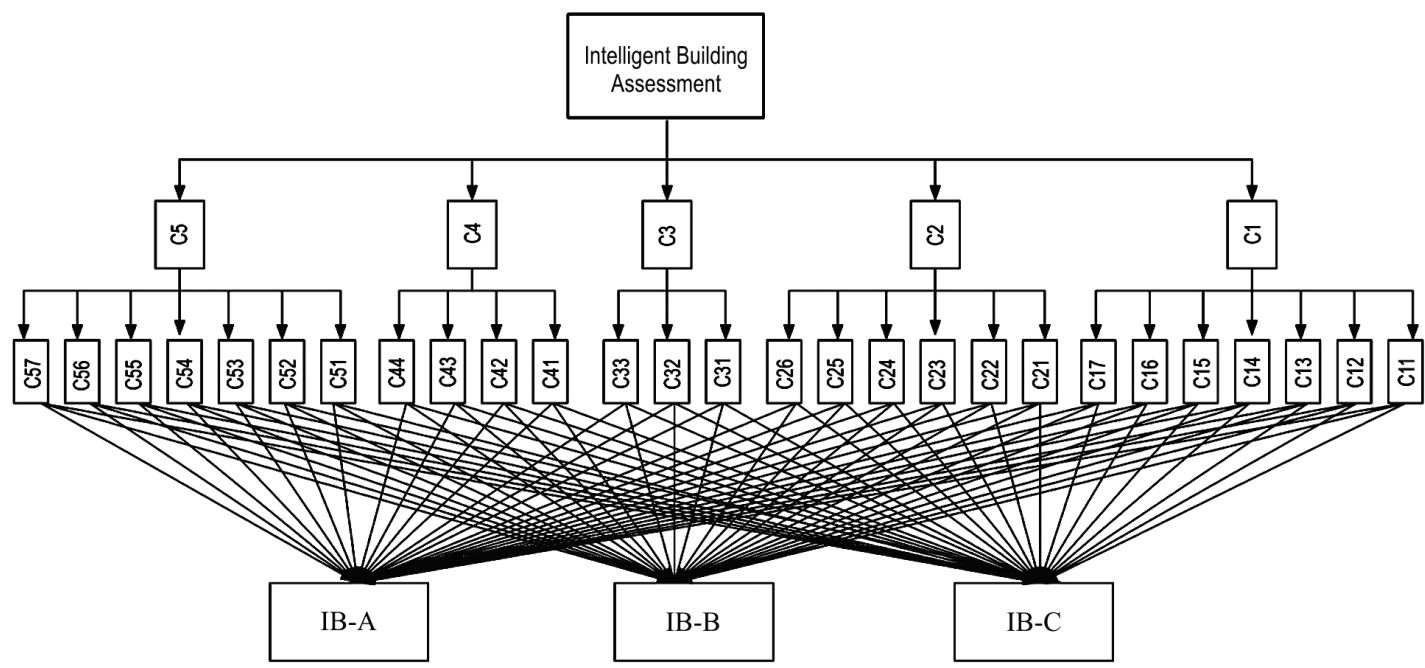

Figure 1 The hierarchical structure of the intelligent building assessment problem

Table 4 criteria and sub-criteria for intelligent building assessment

\begin{tabular}{|c|c|}
\hline \multirow{7}{*}{ Engineering $(\mathrm{C} 1)$} & Functionality (C11) \\
\hline & Safety and structure (C12) \\
\hline & Working efficiency (C13) \\
\hline & Responsiveness (C14) \\
\hline & Office automation (C15) \\
\hline & Power supply (C16) \\
\hline & System integration (C17) \\
\hline \multirow{6}{*}{ Environmental (C2) } & Energy consumption (C21) \\
\hline & Water and Water Conservation (C22) \\
\hline & Materials used, Durability and Waste(C23) \\
\hline & Land use and Site selection (C24) \\
\hline & Greenhouse Gas Emissions (Pollution) (C25) \\
\hline & Indoor Environmental Quality (C26) \\
\hline \multirow{3}{*}{ Economical (C3) } & Economic performance and affordability (C31) \\
\hline & Initial costs, operating and maintenance costs (C32) \\
\hline & Life cycle costing (C33) \\
\hline \multirow{4}{*}{ Socio-Cultural (C4) } & Functionality, Usability and Aesthetic aspects (C41) \\
\hline & Human comfort (C42) \\
\hline & Health and sanitation (C43) \\
\hline & Architectural considerations - cultural heritage integration and the compatibility with local heritage value (C44) \\
\hline \multirow{7}{*}{ Technological (C5) } & Work efficiency (C51) \\
\hline & Use of high-tech system (C52) \\
\hline & Use of advanced artificial intelligence(C53) \\
\hline & Telecom and data system- Connectibility (C54) \\
\hline & Security monitoring and access control system (C55) \\
\hline & Addressable fire detection and alarm system (C56) \\
\hline & Digital addressable lighting control system (C57) \\
\hline
\end{tabular}




\begin{tabular}{|c|c|c|c|c|c|}
\hline & $\mathrm{C} 1$ & $\mathrm{C} 2$ & $\mathrm{C} 3$ & $\mathrm{C} 4$ & $\mathrm{C} 5$ \\
\hline $\mathrm{C} 1$ & $\left(\begin{array}{lll}1 & 1 & 1\end{array}\right)$ & $(3,4095,43914,561)$ & $(4,2136,37,937)$ & $(357)$ & $(0,574 \quad 1 \quad 1,732)$ \\
\hline $\mathrm{C} 2$ & $(0,1340,1840,293)$ & $\left(\begin{array}{lll}1 & 1 & 1\end{array}\right)$ & $(2,9433,956$ 6,422) & $(11,3163,409)$ & $(0,1240,1670,257)$ \\
\hline C3 & $(0,1260,1590,237)$ & $(0,1560,2530,34)$ & $\left(\begin{array}{lll}1 & 1 & 1\end{array}\right)$ & $(0,1240,1670,257)$ & $(0,1170,1360,19)$ \\
\hline $\mathrm{C} 4$ & $(0,1430,20,333)$ & $(0,2930,761)$ & $(3,8925,9768,058)$ & $\left(\begin{array}{lll}1 & 1 & 1\end{array}\right)$ & $(0,1530,2270,435)$ \\
\hline $\mathrm{C} 5$ & $(0,57711,741)$ & $(3,8925,9768,058)$ & $(5,2737,3718,559)$ & $(2,2974,4126,534)$ & $\left(\begin{array}{lll}1 & 1 & 1\end{array}\right)$ \\
\hline
\end{tabular}

Table 6 The fuzzy local and fuzzy global weights of criteria and sub-criteria

\begin{tabular}{|c|c|c|c|c|c|c|c|c|}
\hline Criteria & Fuzzy weight of criteria & Sub-criteria & \multicolumn{3}{|c|}{ Fuzzy weight of sub-criteria } & \multicolumn{3}{|c|}{ Fuzzy global weights } \\
\hline \multirow{7}{*}{$\mathrm{c} 1$} & \multirow{7}{*}{$\left(\begin{array}{llll}0,181 & 0,381 & 0,842)\end{array}\right.$} & $\mathrm{C} 11$ & \multicolumn{3}{|c|}{$(0,1670,3580,697)$} & \multicolumn{3}{|c|}{$(0,0300,1360,587)$} \\
\hline & & $\mathrm{C} 12$ & $(0,017$ & 0,035 & $0,078)$ & $(0,003$ & 0,013 & $0,066)$ \\
\hline & & $\mathrm{C} 13$ & $(0,046$ & 0,114 & $0,271)$ & $(0,008$ & 0,043 & $0,228)$ \\
\hline & & $\mathrm{C} 14$ & $(0,025$ & 0,048 & $0,143)$ & $(0,005$ & 0,018 & $0,120)$ \\
\hline & & $\mathrm{C} 15$ & $(0,18$ & 0,359 & $0,752)$ & $(0,033$ & 0,137 & $0,633)$ \\
\hline & & C16 & $(0,013$ & 0,028 & $0,063)$ & $(0,002$ & 0,011 & $0,053)$ \\
\hline & & C17 & $(0,022$ & 0,057 & $0,127)$ & $(0,004$ & 0,022 & $0,107)$ \\
\hline \multirow{6}{*}{$\mathrm{c} 2$} & \multirow{6}{*}{$(0,0520,0950,219)$} & $\mathrm{C} 21$ & $(0,016$ & 0,034 & $0,094)$ & $(0,001$ & 0,003 & $0,021)$ \\
\hline & & $\mathrm{C} 22$ & $(0,02$ & 0,05 & $0,101)$ & $(0,001$ & 0,005 & $0,022)$ \\
\hline & & $\mathrm{C} 23$ & $(0,214$ & 0,47 & $0,976)$ & $(0,011$ & 0,045 & $0,214)$ \\
\hline & & $\mathrm{C} 24$ & $(0,121$ & 0,276 & $0,668)$ & $(0,006$ & 0,026 & $0,146)$ \\
\hline & & $\mathrm{C} 25$ & $(0,031$ & 0,069 & $0,194)$ & $(0,002$ & 0,007 & $0,042)$ \\
\hline & & $\mathrm{C} 26$ & $(0,038$ & 0,101 & $0,236)$ & $(0,002$ & 0,010 & $0,052)$ \\
\hline \multirow{3}{*}{ c3 } & \multirow{3}{*}{$(0,0190,0340,065)$} & $\mathrm{C} 31$ & $(0,058$ & 0,107 & $0,225)$ & $(0,001$ & 0,004 & $0,015)$ \\
\hline & & $\mathrm{C} 32$ & $(0,062$ & 0,13 & $0,224)$ & $(0,001$ & 0,004 & $0,015)$ \\
\hline & & C33 & $(0,395$ & 0,762 & $1,493)$ & $(0,008$ & 0,026 & $0,097)$ \\
\hline \multirow{4}{*}{$\mathrm{c} 4$} & \multirow{4}{*}{$(0,0450,0990,204)$} & $\mathrm{C} 41$ & $(0,041$ & 0,101 & $0,201)$ & $(0,002$ & 0,010 & $0,041)$ \\
\hline & & $\mathrm{C} 42$ & $(0,194$ & 0,495 & $1,17)$ & $(0,009$ & 0,049 & $0,239)$ \\
\hline & & $\mathrm{C} 43$ & $(0,098$ & 0,219 & $0,59)$ & $(0,004$ & 0,022 & $0,120)$ \\
\hline & & $\mathrm{C} 44$ & $(0,079$ & 0,185 & $0,469)$ & $(0,004$ & 0,018 & $0,096)$ \\
\hline \multirow{7}{*}{ c5 } & \multirow{7}{*}{$(0,1840,3910,75)$} & C51 & $(0,069$ & 0,155 & $0,404)$ & $(0,013$ & 0,061 & $0,303)$ \\
\hline & & $\mathrm{C} 52$ & $(0,152$ & 0,387 & $0,918)$ & $(0,028$ & 0,151 & $0,689)$ \\
\hline & & $\mathrm{C} 53$ & $(0,041$ & 0,151 & $0,364)$ & $(0,008$ & 0,059 & $0,273)$ \\
\hline & & $\mathrm{C} 54$ & $(0,06$ & 0,142 & $0,47)$ & $(0,011$ & 0,056 & $0,353)$ \\
\hline & & $\mathrm{C} 55$ & $(0,026$ & 0,073 & $0,183)$ & $(0,005$ & 0,029 & $0,137)$ \\
\hline & & C56 & $(0,02$ & 0,053 & $0,148)$ & $(0,004$ & 0,021 & $0,111)$ \\
\hline & & $\mathrm{C} 57$ & $(0,016$ & 0,04 & $0,115)$ & $(0,003$ & 0,016 & $0,086)$ \\
\hline
\end{tabular}

Table 7 The fuzzy weighted normalized decision matrix

\begin{tabular}{|c|c|c|c|c|c|c|c|c|c|}
\hline \multirow{3}{*}{$\begin{array}{l}\mathrm{C} 11 \\
\mathrm{C} 12\end{array}$} & \multicolumn{3}{|c|}{ IB-A } & \multicolumn{3}{|c|}{ IB-B } & \multicolumn{3}{|c|}{ IB-C } \\
\hline & \multicolumn{3}{|c|}{$(0,0240,1300,587)$} & $(0,024$ & 0,130 & $0,587)$ & $(0,008$ & 0,061 & $0,381)$ \\
\hline & $(0,001$ & 0,009 & $0,055)$ & $(0,002$ & 0,013 & $0,066)$ & $(0,001$ & 0,008 & $0,051)$ \\
\hline C13 & $(0,007$ & 0,043 & $0,228)$ & $(0,006$ & 0,040 & $0,228)$ & $(0,006$ & 0,039 & $0,228)$ \\
\hline $\mathrm{C} 14$ & $(0,003$ & 0,016 & $0,118)$ & $(0,004$ & 0,018 & $0,120)$ & $(0,003$ & 0,016 & $0,118)$ \\
\hline $\mathrm{C} 15$ & $(0,021$ & 0,116 & $0,621)$ & $(0,026$ & 0,130 & $0,633)$ & $(0,021$ & 0,116 & $0,621)$ \\
\hline $\mathrm{C} 16$ & $(0,000$ & 0,005 & $0,039)$ & $(0,001$ & 0,008 & $0,053)$ & $(0,000$ & 0,003 & $0,028)$ \\
\hline $\mathrm{C} 17$ & $(0,001$ & 0,012 & $0,082)$ & $(0,003$ & 0,019 & $0,107)$ & $(0,001$ & 0,010 & $0,072)$ \\
\hline $\mathrm{C} 21$ & $(0,000$ & 0,001 & $0,011)$ & $(0,000$ & 0,002 & $0,014)$ & $(0,001$ & 0,003 & $0,021)$ \\
\hline $\mathrm{C} 22$ & $(0,000$ & 0,003 & $0,022)$ & $(0,000$ & 0,003 & $0,022)$ & $(0,000$ & 0,003 & $0,022)$ \\
\hline $\mathrm{C} 23$ & $(0,009$ & 0,042 & $0,214)$ & $(0,009$ & 0,042 & $0,214)$ & $(0,003$ & 0,022 & $0,145)$ \\
\hline $\mathrm{C} 24$ & $(0,003$ & 0,018 & $0,136)$ & $(0,003$ & 0,019 & $0,146)$ & $(0,002$ & 0,016 & $0,127)$ \\
\hline $\mathrm{C} 25$ & $(0,000$ & 0,003 & $0,031)$ & $(0,001$ & 0,006 & $0,042)$ & $(0,001$ & 0,006 & $0,042)$ \\
\hline C26 & $(0,002$ & 0,009 & $0,052)$ & $(0,002$ & 0,010 & $0,052)$ & $(0,002$ & 0,009 & $0,052)$ \\
\hline C31 & $(0,001$ & 0,004 & $0,015)$ & $(0,001$ & 0,003 & $0,015)$ & $(0,001$ & 0,003 & $0,015)$ \\
\hline C32 & $(0,001$ & 0,004 & $0,015)$ & $(0,001$ & 0,004 & $0,015)$ & $(0,001$ & 0,003 & $0,012)$ \\
\hline C33 & $(0,001$ & 0,006 & $0,044)$ & $(0,005$ & 0,021 & $0,092)$ & $(0,005$ & 0,023 & $0,097)$ \\
\hline C41 & $(0,001$ & 0,009 & $0,041)$ & $(0,002$ & 0,010 & $0,041)$ & $(0,001$ & 0,009 & $0,041)$ \\
\hline $\mathrm{C} 42$ & $(0,005$ & 0,039 & $0,222)$ & $(0,008$ & 0,049 & $0,239)$ & $(0,005$ & 0,037 & $0,215)$ \\
\hline $\mathrm{C} 43$ & $(0,001$ & 0,011 & $0,084)$ & $(0,004$ & 0,022 & $0,120)$ & $(0,004$ & 0,022 & $0,120)$ \\
\hline $\mathrm{C} 44$ & $(0,003$ & 0,017 & $0,096)$ & $(0,001$ & 0,011 & $0,077)$ & $(0,002$ & 0,012 & $0,079)$ \\
\hline C51 & $(0,008$ & 0,052 & $0,297)$ & $(0,010$ & 0,058 & $0,303)$ & $(0,008$ & 0,048 & $0,288)$ \\
\hline C52 & $(0,019$ & 0,132 & $0,689)$ & $(0,019$ & 0,132 & $0,689)$ & $(0,019$ & 0,132 & $0,689)$ \\
\hline C53 & $(0,005$ & 0,049 & $0,259)$ & $(0,007$ & 0,059 & $0,273)$ & $(0,005$ & 0,052 & $0,268)$ \\
\hline C54 & $(0,008$ & 0,052 & $0,353)$ & $(0,010$ & 0,056 & $0,353)$ & $(0,006$ & 0,042 & $0,317)$ \\
\hline C55 & $(0,002$ & 0,015 & $0,102)$ & $(0,000$ & 0,006 & $0,058)$ & $(0,003$ & 0,024 & $0,137)$ \\
\hline C56 & $(0,001$ & 0,011 & $0,083)$ & $(0,001$ & 0,012 & $0,089)$ & $(0,003$ & 0,020 & $0,111)$ \\
\hline C57 & $(0,000$ & 0,006 & $0,058)$ & $(0,001$ & 0,012 & $0,086)$ & $(0,001$ & 0,012 & $0,086)$ \\
\hline
\end{tabular}

Finally, we applied the fuzzy DEA model presented in Section 2 on the weighted normalized fuzzy decision matrix. To this end, the intelligent building alternatives, i.e., IB-A, IB-B, and IB-C, are considered as DMUs in the FDEA model. Furthermore, all sub-criteria are considered as the output variables and a fuzzy number $\left(\begin{array}{lll}1 & 1 & 1\end{array}\right)$ is considered as a dummy input for each DMU. Then, the FDEA model is solved for each DMU to determine its rank. The score and ranking results for each DMU are reported in Tab. 8. The FDEA model determines the score 
of 1 for all alternative at $\alpha=1$, and hence cannot discriminate alternatives at this $\alpha$-level. However, according to these results, it can be affirmed that at each $\alpha$-level except $\alpha=1$, the best alternative is alternative IB-B for an intelligent building. Furthermore, IB-C is the worst alternative. Therefore, at each $\alpha$-level, the ranking of alternatives is determined as IB-B $>$ IB-A $>$ IB-C. This ranking result is also consistent with that obtained by fuzzy MAUT introduced by Kahraman and Kaya [17], and fuzzy TOPSIS and fuzzy AHP developed in [18]. As highlighted in [20], the higher value for $\alpha$ is better. Therefore, the results obtained under $\alpha=1$ are of interest. However, under this $\alpha$-level, the decision alternatives are not discriminated. Therefore, it is logical to select $\alpha=0,75$ to obtain the overall results, which are IB-B $>$ IB-A $>$ IBC.

Table 8 The score and ranking results obtained by FDEA model

\begin{tabular}{|c|c|c|c|c|}
\hline \multirow{2}{*}{ Alternative } & \multicolumn{4}{|c|}{ Score (ranking) } \\
\cline { 2 - 5 } & $\alpha=0,25$ & $\alpha=0,5$ & $\alpha=0,75$ & $\alpha=1$ \\
\hline IB-A & $7,33(2)$ & $6,95(2)$ & $5,67(2)$ & $1(1)$ \\
\hline IB-B & $7,59(1)$ & $7,01(1)$ & $5,83(1)$ & $1(1)$ \\
\hline IB-C & $7,53(3)$ & $6,81(3)$ & $4,87(3)$ & $1(1)$ \\
\hline
\end{tabular}

\section{Concluding remarks}

An intelligent building is a useful approach to provide sustainable, responsive, effective and supportive environment and help individuals and organizations to achieve their objectives. An intelligent building is responsible to obtain sustainability, energy effectiveness, intelligent technologies and practices letting more and better to be delivered for less. It offers a sustainable, responsive, effective and helpful environment which helps organizations to accomplish their objectives. This paper proposed an integrated FAHP-FDEA to assess intelligent building alternatives. The proposed model utilized the fuzzy set theory to handle the imprecise and vague data of evaluation criteria. Since the evaluation criteria do not have an equal importance in the assessment process, the fuzzy AHP is considered to determine the weight of criteria. Then, the determined weight of criteria is used to calculate the weighted normalized fuzzy decision matrix. Finally, the fuzzy DEA model is applied on the weighted normalized fuzzy decision matrix to assess the intelligent building alternatives. The proposed method is applied on a case study taken from the literature. The results affirmed that the proposed model provides the consistent results with the fuzzy MAUT, fuzzy TOPSIS, and fuzzy AHP which were previously developed by Kahramanand Kaya [17] and Kaya and Kahraman [18], respectively.

\section{References}

[1] Harrison, A.; Loe, E.; Read, J. Intelligent Buildings in South East Asia. // London: E \& FN Spon. 1998.

[2] Wigginton, M.; Harris, J. Intelligent Skin. // Oxford, UK, Architectural Press, 2002.

[3] Kroner, W. M. An intelligent and responsive architecture. // Automation in Construction. 6, (1997), pp. 81-393. DOI: 10.1016/S0926-5805(97)00017-4

[4] Wong, K. W. J. Development of selection evaluation and system intelligence analytic models for the intelligent building control systems. // PhD thesis, The Hong Kong Polytechnic University, 2007.

[5] Wong, J.; Li, H. Development of a conceptual model for the selection of intelligent building systems. // Building and Environment. 41, (2006), pp. 1106-1123. DOI: 10.1016/j.buildenv.2005.04.021

[6] Wong, J. K. W.; Li, H.; Wang, S. W. Intelligent building research: a review. // Automation in Construction. 14, (2005), pp. 143-159. DOI: 10.1016/j.autcon.2004.06.001

[7] Hastak M. Advanced automation or conventional construction process. // Automation in Construction. 7, (1998), pp. 299-314. DOI: 10.1016/S0926-5805(98)00047-8

[8] Chen, Z.; Clements-Croome, D.; Hong, J.; Li, H.; Xu, Q. A multi criteria lifespan energy efficiency approach to intelligent building assessment. // Energy and Buildings. 38, 5(2006), pp. 393-409. DOI: 10.1016/j.enbuild.2005.08.001

[9] Kolokotsa, D.; Sutherland, G.; Stavrakakis, G.; Karatassou, S.; Santamouris, M. A matrix tool for assessing the performance of intelligent buildings. // Management of Environmental Quality: an International Journal. 18, 1(2007), pp. 36-49. DOI: 10.1108/14777830710717703

[10] Wong, J. K. W.; Li, H. Application of the analytic hierarchy process (AHP) in multi-criteria analysis of the selection of intelligent building systems. // Building and Environment. 43, 1(2008), pp. 108-125. DOl: 10.1016/j.buildenv.2006.11.019

[11] Alwaer, H.; Clements-Croome, D. J. Key performance indicators (KPIs) and priority setting in using the multi attribute approach for assessing sustainable intelligent buildings. // Building and Environment. 45, 4(2010), pp. 799-807. DOI: 10.1016/j.buildenv.2009.08.019

[12] Hong, J.; Chen, Z.; Li, H.; Xu, Q. An information visualization approach to intelligent building assessment. // in the Proceedings of the 6th International Conference for Enhanced Building Operations. November 6-9, 2006, Shenzhen, China, 2006.

[13] So, A. T. P.; Wong, K. C. On the quantitative assessment of intelligent building. // Facilities. 20, 5-6(2002), pp. 208216.

[14] Preiser, W. F. E.; Schramm, U. Intelligent office building performance evaluation. // Facilities. 20, 7-8(2002), pp. 279-287.

[15] Arkin, H.; Paciuk, M. Evaluating intelligent buildings according to level of service system integration. // Automation in Construction. 6, 5-6(1997), pp. 471-479.

[16] Yang, J.; Peng, H. Decision support to the application of intelligent building technologies. // Renewable Energy. 22, 1-3(2001), pp. 67-77.

[17] Kahraman, C.; Kaya, İ. A fuzzy multiple attribute utility model for intelligent building assessment. // Journal of Civil Engineering and Management. 18, 6(2012), pp. 811-820. DOI: $10.3846 / 13923730.2012 .720932$

[18] Kaya, İ.; Kahraman, C. A comparison of fuzzy multi criteria decision making methods for intelligent building assessment. // Journal of Civil Engineering and Management. 20, 1(2014), pp. 59-69. DOI: 10.3846/13923730.2013.801906

[19] Charnes, W.; Cooper, W.; Rhodes, E. Measuring the Efficiency of Decision Making Units. // European Journal of Operational Research. 2, (1978), pp. 429-444. DOl: 10.1016/0377-2217(78)90138-8

[20] Saati, S. M.; Memariani, A.; Jahanshahloo, G. R. Efficiency Analysis and Ranking of DMUs with Fuzzy Data. // Fuzzy Optimization and Decision Making. 1, 3(2002), pp. 255267. DOI: $10.1023 / \mathrm{A}: 1019648512614$

[21] Hsieh, T. Y.; Lu, S. T.; Tzeng, G. H. Fuzzy MCDM approach for planning and design tenders selection in public office buildings. // International Journal of Project Management. 22, (2004), pp. 573-584. DOI: 10.1016/j.jproman.2004.01.002 
[22] Liu, W. B.; Zhang, D. Q.; Meng, W.; Li, X. X.; Xu, F. A Study of DEA Models without Explicit Inputs. // Omega. 39, (2011), pp. 472-480. DOI: 10.1016/j.omega.2010.10.005

\section{Authors' addresses}

Afshar Sahraei Loron, Postgraduate Student

Faculty of Civil and Architecture,

Science and Research Branch,

Islamic Azad University, Semnan, Iran

E-mail: afsharsahraei.loron@gmail.com

Mehrdad Sahraei Loron (Corresponding author)

Faculty of Design and Architecture,

University Putra Malaysia, Malaysia

Ghazal Peyvandi, Postgraduate Student,

Faculty of Civil and Architecture,

Science and Research Branch,

Islamic Azad University, Semnan, Iran 